DOI: $10.15193 /$ zntj/2018/117/259

\author{
AGNIESZKA NEMŚ, ANNA PĘKSA, AGNIESZKA KITA, \\ JOANNA MIEDZIANKA, ELŻBIETA RYTEL, AGNIESZKA TAJNER-CZOPEK

\section{JAKOŚĆ SUSZY I CHRUPEK Z ZIEMNIAKÓW ODMIAN O FIOLETOWEJ I CZERWONEJ BARWIE MIĄŻSZU}

\begin{abstract}
Streszczenie
Celem pracy było określenie zawartości polifenoli ogółem, aktywności przeciwutleniającej i barwy suszy otrzymanych z ziemniaków o fioletowym i czerwonym miąższu, blanszowanych w roztworach kwasów organicznych, oraz uzyskanych z ich udziałem chrupek. Surowcem do badań był susz otrzymany $\mathrm{z}$ bulw ziemniaków blanszowanych w roztworach kwasu winowego (odmiany fioletowe) lub cytrynowego (odmiany czerwone), stanowiący półprodukt do produkcji peletów, z których po wysmażeniu otrzymano chrupki ziemniaczane. W suszu i chrupkach oznaczono zawartość polifenoli, aktywność przeciwutleniającą i barwę. Ponadto w przekąskach analizowano zawartość tłuszczu, twardość, stopień ekspansji oraz przeprowadzono ocenę sensoryczną.

Stwierdzono, że blanszowanie ziemniaków o barwnym miąższu w roztworach kwasów organicznych pozwoliło na zachowanie znacznej ilości polifenoli w suszach, jednak nie wpłynęło na zahamowanie zmian wywołanych obróbką termiczną, tzw. ciemnienia chemicznego. Susze z odmian ziemniaków o fioletowym miąższu były beżowo-fioletowe, brązowo-fioletowe bądź fioletowe, a otrzymane $\mathrm{z}$ nich chrupki - beżowe. Susze z ziemniaków o czerwonym miąższu zachowały różową barwę, a otrzymane z nich chrupki były beżowo-różowe bądź różowe. Chrupki z suszu odmian ziemniaków o barwnym miąższu zawierały więcej polifenoli $(4 \div 116 \%)$ i wykazywały wyższą aktywność przeciwutleniającą oznaczoną w reakcji $\mathrm{DPPH}^{*}(3,5-\div 5$-krotnie $), \mathrm{ABTS}^{++}(2,3-\div 4$-krotnie $)$ oraz metodą FRAP $(1,2-\div$ 2,5-krotnie) w porównaniu z chrupkami na bazie grysu ziemniaczanego. Użycie suszu z ziemniaków o fioletowej i czerwonej barwie miąższu pozwoliło na otrzymanie chrupek charakteryzujących się akceptowanymi cechami sensorycznymi, jednak ze względu na istotną rolę barwy w akceptacji konsumenckiej należy zmodyfikować sposób otrzymywania suszy z surowca o barwnym miąższu.
\end{abstract}

Słowa kluczowe: ziemniaki o fioletowej i czerwonej barwie miąższu, blanszowanie, susze, chrupki, barwa, polifenole, aktywność przeciwutleniająca

Dr inż. A. Nemś, prof. dr hab. inż. A. Pęksa, prof. dr hab. inż. A. Kita, dr inż. J. Miedzianka, dr hab. inż. E. Rytel, dr hab. inz. A. Tajner-Czopek, prof. nadzw., Katedra Technologii Rolnej i Przechowalnictwa, Wydz. Biotechnologii i Nauk o Żywności, Uniwersytet Przyrodniczy we Wroctawiu, ul. Chetmońskiego 37,51-630Wrocław.Kontakt:agnieszka.nems@upwr.edu.pl 


\section{Wprowadzenie}

Ekstrudowane przekąski (chrupki) stanowią liczną grupę produktów charakteryzującą się niewielkimi rozmiarami i różnymi kształtami. Na atrakcyjność tych wyrobów mają wpływ takie cechy sensoryczne, jak chrupkość, smak i porowata struktura. W grupie wyrobów przekąskowych ekspandowanych przeważają produkty otrzymywane w wyniku smażenia lub prażenia peletów lub ukształtowanych kawałków ciasta, określane jako przekąski (chrupki) III generacji (ang. pellets' snacks lub Third Generation Snacks). Podstawowym surowcem do ich produkcji są ziemniaki lub otrzymywane z nich przetwory, takie jak grys, płatki czy granulat ziemniaczany.

Preferencje i nawyki żywieniowe konsumentów uległy zmianie w przeciągu ostatnich lat. Konsumenci poszukują produktów, które z jednej strony charakteryzują się odpowiednim smakiem, atrakcyjnym wyglądem, a z drugiej zawierają składniki żywieniowe, takie jak: makro- i mikroelementy, białko czy błonnik [23], stąd też do typowych receptur coraz częściej wprowadzane są nowe składniki [2]. Jako składniki do otrzymywania wyrobów przekąskowych typu chrupki używane są m.in. kaszki lub mąki z nasion roślin strączkowych, mąki warzywne, orzechowe, migdałowe, rybne i inne zawierające znaczne ilości białka, błonnika i tłuszczu [20]. Dodatek białka przyczynia się do zwiększenia wartości odżywczej, a wprowadzenie błonnika zmniejsza wartość energetyczną i strawność wyrobów [24].

Ważnym kierunkiem jest poszerzanie asortymentu przekąsek poprzez wzbogacanie składu surowcowego w składniki prozdrowotne [16] oraz nadające produktom atrakcyjny wygląd. Takimi surowcami mogą być ziemniaki i przetwory ziemniaczane $\mathrm{z}$ bulw o czerwonym bądź fioletowym miąższu [18]. Bulwy tych odmian ziemniaków odznaczają się intensywnym zabarwieniem dzięki obecności antocyjanów będących pochodnymi pelargonidyny, peonidyny, petunidyny i malwidyny. Bulwy o czerwonym miąższu zawierają głównie glikozydy pelargonidynowe $(200 \div 2000 \mathrm{mg} / \mathrm{kg})$, a o fioletowym - pochodne petunidyny i malwidyny $(2000 \div 5000 \mathrm{mg} / \mathrm{kg})$. Całkowita zawartość antocyjanów w ziemniakach o czerwonym miąższu wynosi $69 \div 350 \mathrm{mg} / \mathrm{kg}$, natomiast $\mathrm{w}$ bulwach o fioletowym miąższu $-55 \div 171 \mathrm{mg} / \mathrm{kg}$ [19]. Dzięki dużej zawartości związków polifenolowych, w tym antocyjanów, ziemniaki odmian o barwnym miąższu charakteryzują się $2-\div 3$-krotnie wyższą aktywnością przeciwutleniającą in vitro w porównaniu z bulwami tradycyjnych odmian [18]. Antocyjany należą jednak do związków nietrwałych, które są degradowane podczas obróbki termicznej oraz łatwo ulegają przemianom pod wpływem zmiany $\mathrm{pH}$ [5]. W środowisku kwaśnym $(\mathrm{pH}<2)$ mają barwę czerwoną dzięki obecności kationu flawyliowego. Wraz ze wzrostem pH udział tego kationu maleje, a wzrasta udział bezbarwnej pseudozasady karbinolowej, która wraz ze wzrostem pH przekształca się w chalkon o barwie niebieskiej. W związku z tym antocyjany w środowisku obojętnym $(\mathrm{pH}=7)$ mają barwę fioletową, natomiast $\mathrm{w}$ środowisku zasadowym $(\mathrm{pH}>11)$ ich barwa staje się niebieska [6]. 
Podczas przemysłowej produkcji suszy ziemniaczanych istotnym zabiegiem technologicznym jest sulfitacja. Proces ten może być wykonywany jako odrębny po blanszowaniu lub też połączony z blanszowaniem. Siarkowanie ma na celu zapobieganie zmianom barwy suszy poprzez blokowanie czynnych grup funkcyjnych substratów reakcji Maillarda [30]. Sulfitacja produktów zawierających antocyjany powoduje ich stopniowe odbarwianie poprzez tworzenie bezbarwnych kompleksów, pochodnych siarkowych antocyjanów [6]. W związku z tym wydaje się zasadne, aby do blanszowania ziemniaków o barwnym miąższu, bogatych w antocyjany, użyć roztworów niezawierających $\mathrm{SO}_{2}$, takich jak roztwory kwasów organicznych.

Niezbędne wydaje się także określenie stabilności związków bioaktywnych zawartych w ziemniakach o barwnym miąższu w kolejnych etapach przetwarzania $\mathrm{i}$ ich wpływu na cechy sensoryczne gotowego produktu.

Celem pracy było oznaczenie zawartości polifenoli ogółem, aktywności przeciwutleniającej i barwy suszy otrzymanych z ziemniaków o fioletowym i czerwonym miąższu, blanszowanych w roztworach kwasów organicznych oraz określenie jakości chrupek uzyskanych z ich udziałem.

\section{Material i metody badań}

Surowcem do badań były susze otrzymane z bulw 6 odmian ziemniaków o fioletowej barwie miąższu ('Blaue Saint Galler', 'Blue Star', 'Fleur Blue', 'Valfi', 'Blue Congo', 'Bora Valley') i 2 - o czerwonej ('Rosalinde', 'Highland Burgundy Red') pochodzących z sezonu wegetacyjnego 2016 roku. Ziemniaki pochodziły z Uniwersytetu Rolniczego w Pradze. Do sporządzenia suszy użyto po 5 kg każdej odmiany ziemniaków.

Susz używany do produkcji smażonych przekąsek otrzymywano według schematu przedstawionego na rys. 1. Zastosowano blanszowanie talarków ziemniaków o grubości ok. $1 \mathrm{~cm}$ w 0,3-procentowych roztworach słabych kwasów organicznych, w temp. $90{ }^{\circ} \mathrm{C}$ przez 5 min. Talarki ziemniaków odmian o fioletowym miąższu blanszowano w roztworze kwasu winowego o $\mathrm{pH}$ 2,6, natomiast odmian o czerwonym miąższu - w roztworze kwasu cytrynowego o pH 2,8. Roztwory kwasów dobrano na podstawie badań wstępnych (dane niepublikowane), w których stwierdzono, że roztworem pozwalającym na zachowanie najkorzystniejszej barwy ziemniaków o czerwonym i fioletowym miąższu są odpowiednio roztwory kwasu cytrynowego i winowego. Ciasto sporządzano ze skrobi ziemniaczanej (PPZ SA w Niechlowie) - $67 \%$, suszy z ziemniaków o fioletowej i czerwonej barwie miąższu - $26 \%$ oraz mąki kukurydzianej (Melvit SA Warszawa) - $5 \%$ i soli - $2 \%$, które następnie nawilżano do wilgotności ok. 40 \%. Próbę kontrolną stanowiło ciasto, w którym mąkę z ziemniaków o fioletowym i czerwonym miąższu zastąpiono przemysłowym grysem ziemniaczanym. 


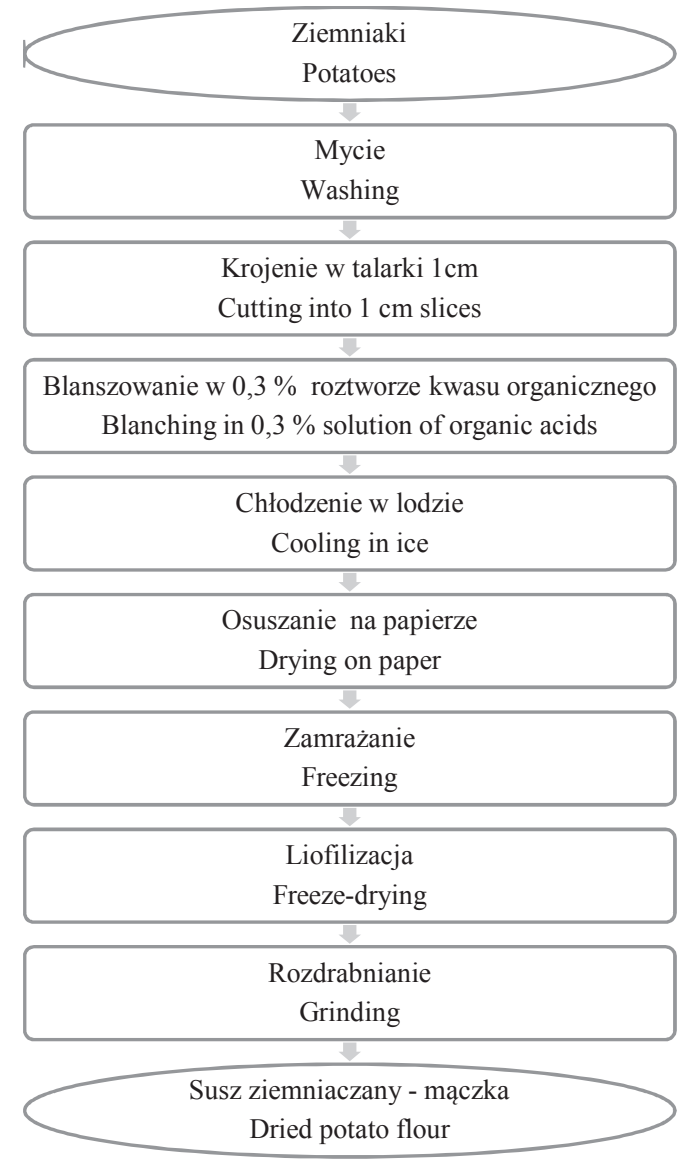

Rys. 1. Schemat otrzymywania suszu z ziemniaków odmian o fioletowym i czerwonym miąższu

Fig. 1. The scheme of preparation the dried potato flours from coloured flesh varieties

Przygotowane ciasto (400 g) ekstrudowano w jednoślimakowym ekstruderze (Brabender DN 20, Niemcy). Stosowano matrycę o rozmiarze $0,5 \mathrm{~mm} \times 80 \mathrm{~mm}$, szybkość podawania ciasta $38 \mathrm{obr}$./min, szybkość ślimaka $120 \mathrm{obr} . / \mathrm{min}$, obciążenie ślimaka 2,8 A, rozkład temperatury w komorze ekstrudera $\left[{ }^{\circ} \mathrm{C}\right]: 60 / 70 / 80$. Uzyskane ekstrudowane, nieekspandowane ciasto cięto na pelety o wymiarach $27 \times 27 \mathrm{~mm}$ i suszono w temp. $23 \pm 2{ }^{\circ} \mathrm{C}$ przez $12 \mathrm{~h}$ do wilgotności ok. $12 \%$, a następnie w celu jej zrównoważenia pelety zamykano $\mathrm{w}$ workach polietylenowych aż do momentu smażenia. Wytworzono ok. 150 g peletów każdej z prób. Chrupki otrzymywano poprzez smażenie porcji peletów w rafinowanym oleju rzepakowym w temp. $185^{\circ} \mathrm{C}$ przez $15 \mathrm{~s}$. Stosunek produktu do oleju utrzymywano na poziomie $1: 20(\mathrm{~m} / \mathrm{v})$. Doświadczenie wykonano w 2 powtórzeniach technologicznych. 
W otrzymanym laboratoryjnie suszu z ziemniaków o fioletowym i czerwonym miąższu i w chrupkach oznaczano zawartości polifenoli ogółem, aktywność przeciwutleniającą i barwę. W wyprodukowanych chrupkach oznaczano zawartość tłuszczu, twardość i stopień ekspansji. Przeprowadzono także ich ocenę sensoryczną.

Polifenole ekstrahowano z suszu i odtłuszczonych wcześniej chrupek za pomocą 70-procentowego wodnego roztworu acetonu według metody opisanej przez Nemś i wsp. [21]. W uzyskanych ekstraktach metodami spektrofotometrycznymi (spektrofotometr Reileigh UV-2601, Chiny) oznaczano całkowitą zawartość polifenoli metodą Folina-Ciocalteu [8], aktywność przeciwutleniającą (TEAC) z wykorzystaniem kationorodników $\mathrm{ABTS}^{\circ+}$ [25], rodników $\mathrm{DPPH}^{*}$ [29] i jako zdolność redukcji jonów żelaza - FRAP [4]. Sporządzono krzywe wzorcowe odpowiednio w zakresach $0 \div 200 \mu \mathrm{g}$ kwasu galusowego/ml (polifenole ogółem), $0 \div 2 \mu \mathrm{mol}$ Troloxu/ml $\left(\right.$ ABTS $^{\circ+}$ ), $0 \div$ $340 \mathrm{nmol}$ Troloxu/ml (DPPH'), $0 \div 450 \mathrm{nmol}$ Troloxu/ml (FRAP). Zawartość tłuszczu w przekąskach oznaczano metodą ekstrakcyjną Soxhleta [1]. Barwę w systemie CIE $\mathrm{L} * \mathrm{C} * \mathrm{~h} *$ mierzono za pomocą spektrofotometru Konica Minolta CM-5 (Konica Minolta, Japonia) względem białego wzorca odniesienia. Stosowano źródło światła D65. Twardość chrupek określano za pomocą teksturometru Instron, typ 5544 (Instron, USA) z oprogramowaniem Merlin. Minimalną siłę [N] niezbędną do przecięcia przekąski mierzono za pomocą przystawki w formie gilotyny o prędkości przesuwu noża $250 \mathrm{~mm} / \mathrm{min}$. Stopień ekspansji przekąsek obliczano jako iloraz wielkości przekąski do wielkości peletu.

Ocenę właściwości sensorycznych chrupek wykonywano według metodyki podanej przez Baryłko-Pikielną i Matuszewską [3]. W próbkach chrupek umieszczonych w oznaczonych kodami cyfrowymi naczynkach oceniano następujące wyróżniki jakości: barwę, smak, zapach, konsystencję i wygląd. Zastosowano 7-punktową skalę ocen (1 - ocena najgorsza, 7 - ocena najlepsza). Oceniano barwę oraz jej intensywność i jednolitość, konsystencję - chrupkość i twardość, wygląd i strukturę - jednolitość ekspansji i pofałdowanie powierzchni przekąsek. Smak i zapach chrupek oceniano pod względem wyczuwalności obcych posmaków i zapachów, w tym zjełczałego tłuszczu i przypalenia. Ocena była dokonywana w pracowni analizy sensorycznej żywności przez przeszkolony 10-osobowy zespół, w którego skład wchodzili pracownicy i studenci Uniwersytetu Przyrodniczego we Wrocławiu.

Analizę statystyczną uzyskanych wyników przeprowadzono przy użyciu jednoczynnikowej analizy wariancji (ANOVA). Do oszacowania różnić między wartościami średnimi badanych wyróżników zastosowano Test Duncana, przy $\mathrm{p}=0,05$. Obliczenia wykonano przy użyciu oprogramowania Statistica v. 12.0. 


\section{Wyniki i dyskusja}

\section{Zawartość polifenoli ogółem i aktywność przeciwutleniająca suszy}

Zawartość polifenoli ogółem w otrzymanych suszach była 4,6- $\div$ 9,8-krotnie większa od zawartości tych związków w przemysłowym grysie ziemniaczanym (tab. 1). Wykazano dodatnią jej korelację $\mathrm{z}$ potencjałem przeciwutleniającym tego surowca, wyrażonym jako zdolność: dezaktywacji kationorodników $\operatorname{ABTS}^{++}(\mathrm{r}=0,963)$, redukcji jonów żelaza FRAP $(r=0,934)$ i rodników DPPH $(r=0,865)$. Reyes i wsp. [27] oraz Reddivari i wsp. [26], Hejtmankova i wsp. [12], Lachman i wsp. [17] także stwierdzili dodatnią korelację między całkowitą zawartością polifenoli, w tym antocyjanów, a aktywnością przeciwutleniającą ziemniaków.

Wśród suszy z ziemniaków o fioletowym miąższu największą zawartością polifenoli ogółem, jak również najwyższą aktywnością przeciwutleniającą, odznaczał się susz z ziemniaków odmiany 'Blue St. Galler' (odpowiednio 2,44 mg GAE/g s.m. polifenoli ogółem, 44,53 $\mu \mathrm{mol}$ TE/g s.m. - ABTS $^{*+}$, 17,06 $\mu$ mol TE/g s.m. - DPPH', $6,72 \mu \mathrm{mol}$ TE/g s.m. - FRAP), a wśród czerwonych - 'Highland Burgundy Red' (2,23 mg GAE/g s.m. polifenoli ogółem, 43,40 $\mu \mathrm{mol} \mathrm{TE/g} \mathrm{s.m.} \mathrm{-}$ ABTS $^{\circ+}, 11,76 \mu \mathrm{mol}$ TE/g s.m. - DPPH', 5,09 $\mu$ mol TE/g s.m. - FRAP) - tab. 1.

Zawartość polifenoli ogółem w otrzymanych suszach była większa, a potencjał przeciwutleniający mniejszy niż w suszach otrzymanych przez Nemś i wsp. [21], którzy zastosowali zabieg blanszowania ziemniaków w roztworze $\mathrm{SO}_{2}$. Większa zawartość polifenoli w badanych suszach wynika z zastosowania roztworów kwasów organicznych o niskim $\mathrm{pH}(2,6$ i 2,8$)$ podczas blanszowania. Umożliwiły one zachowanie znacznej części związków polifenolowych, które są stabilne w środowisku kwaśnym [9]. Na większą aktywność przeciwutleniającą suszy otrzymanych przez Nemś i wsp. [21] prawdopodobnie miała wpływ obecność zastosowanego w blanszowaniu wodorosiarczanu(IV) sodu, którego sposób oddziaływania przeciwutleniającego może być zmierzony za pomocą zastosowanych testów.

\section{Barwa suszy}

Barwa suszy z ziemniaków odmian o fioletowym miąższu była beżowofioletowa, zmieniona w stosunku do surowca ('Bora Valley', 'Blue Congo') lub brązowo-fioletowa ('Blue Star', 'Valfi', 'Fleur Blue') Wyjątek stanowił susz z ziemniaków odmiany 'Blaue St. Galler', który utrzymał barwę fioletową. Susze z bulw odmian o czerwonym miąższu były jasnoróżowe ('Rosalinde') lub różowe ('Highland Burgund Red') - tab. 1. Barwa suszy była z jednej strony determinowana obecnością antocyjanów w surowcu [9], a z drugiej - produktów ciemnienia chemicznego ziemniaków. 


\begin{tabular}{|c|c|c|c|c|c|c|c|c|}
\hline 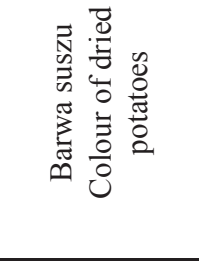 & 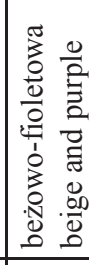 & 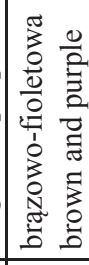 & 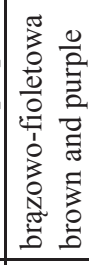 & 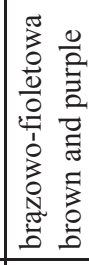 & 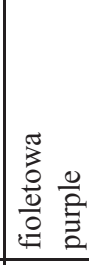 & 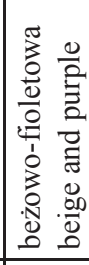 & 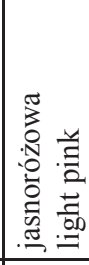 & 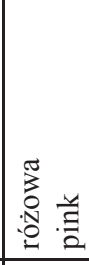 \\
\hline 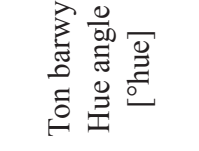 & 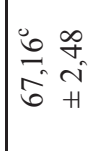 & $\begin{array}{ll}0 & 0 \\
\tilde{n} & 0 \\
\tilde{m} & 0 \\
\tilde{m} & +1\end{array}$ & 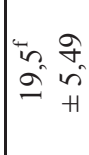 & {$\left[\begin{array}{ll}0 & m \\
0 & 0 \\
0 & 0 \\
0 & 0\end{array}\right.$} & 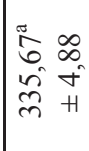 & 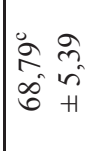 & $\begin{array}{ll}\vec{D} & + \\
\vec{n} & 0 \\
0 & 0 \\
i & 0\end{array}$ & 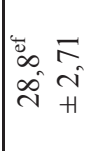 \\
\hline 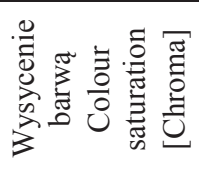 & 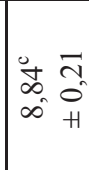 & $\begin{array}{l}n \\
\text { in } \\
\text { n. } \\
\text { nn }\end{array}$ & 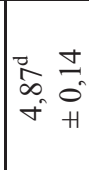 & 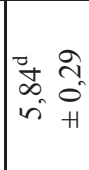 & 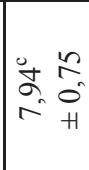 & $\mid$\begin{tabular}{ll}
0 & 0 \\
0 & 0 \\
\hdashline & -1 \\
& +1
\end{tabular} & $\mid$\begin{tabular}{cc}
0 & $\infty$ \\
0 & 0 \\
\cline { 1 - 1 } & 0 \\
\cline { 1 - 1 } & +
\end{tabular} & 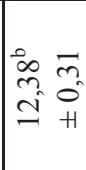 \\
\hline 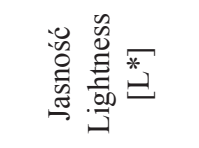 & 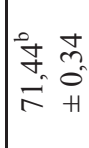 & $\begin{array}{ll}0 & 0 \\
6 & 2 \\
0 & 0 \\
0 & 0 \\
0 & +1\end{array}$ & 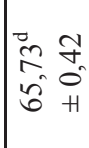 & $\mid \begin{array}{cc}0 & 0 \\
0 & 0 \\
0 & 0 \\
+\end{array}$ & 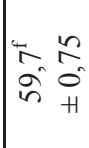 & $\left|\begin{array}{ll}0 & 2 \\
i & 0 \\
0 & 0 \\
0 & 0 \\
0 & +1\end{array}\right|$ & $\mid \begin{array}{cc}i n & \infty \\
i & 0 \\
0 & 0 \\
0 & +1\end{array}$ & $\mid \begin{array}{ll}0 & \overrightarrow{0} \\
\infty & \sigma_{0} \\
\vec{b} & +\end{array}$ \\
\hline 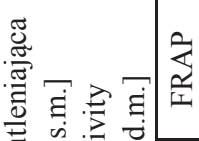 & 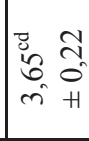 & 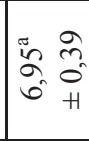 & 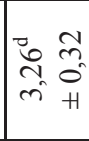 & 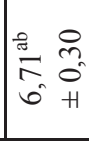 & 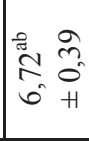 & 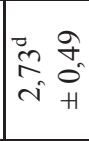 & $\mid \begin{array}{ll}\vec{B} & 0 \\
0 & 0 \\
0 & 0 \\
m & 0\end{array}$ & $\mid \begin{array}{ll}0 & 0 \\
8 & 0 \\
0 & 0 \\
n & 0\end{array}$ \\
\hline 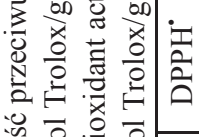 & $\begin{array}{ll}0 & n \\
\infty & \infty \\
= & 0 \\
= & 0 \\
= & +1\end{array}$ & 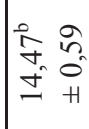 & 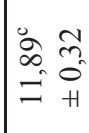 & 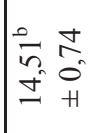 & 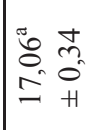 & $\begin{array}{ll}0 & 3 \\
0 & 0 \\
= & 0 \\
= & +1\end{array}$ & $\mid \begin{array}{ll}0 & n \\
0 & n \\
0 & 0 \\
0 & 0 \\
0 & H\end{array}$ & $\mid$\begin{tabular}{ll}
$i$ & \multirow{7}{*}{} \\
$\stackrel{5}{*}$ & 0 \\
$=$ & +
\end{tabular} \\
\hline 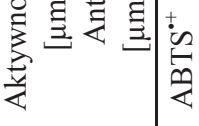 & 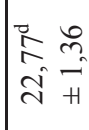 & $\begin{array}{ll}0 & n \\
\infty & n \\
\infty & n \\
\infty & n \\
n & +1\end{array}$ & 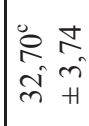 & 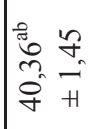 & 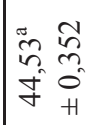 & 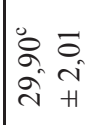 & $\begin{array}{ll}0 & 8 \\
n & 8 \\
i & - \\
m & +1\end{array}$ & 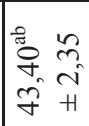 \\
\hline 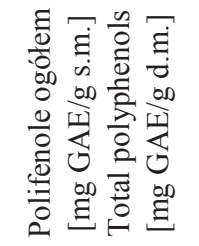 & $\begin{array}{l}8 \\
0 \\
+1 \\
0 \\
0 \\
\Rightarrow \\
ت\end{array}$ & $\begin{array}{l}2 \\
\overrightarrow{0} \\
+1 \\
\frac{0}{m} \\
i \\
i\end{array}$ & $\begin{array}{l}8 \\
0 \\
0 \\
+1 \\
0 \\
0 \\
\\
-1\end{array}$ & $\begin{array}{l}0 \\
0 \\
0 \\
+1 \\
00 \\
0 \\
0 \\
i\end{array}$ & $\begin{array}{l}m \\
0 \\
0 \\
+1 \\
\text { a } \\
\text { in }\end{array}$ & $\begin{array}{l}0 \\
0 \\
+1 \\
i n \\
\text { in } \\
=\end{array}$ & $\begin{array}{l}= \\
0 \\
0+1 \\
0 \\
0 \\
\text { I }\end{array}$ & $\begin{array}{l}\overrightarrow{0} \\
0 \\
+1 \\
\tilde{n} \\
i \\
i\end{array}$ \\
\hline 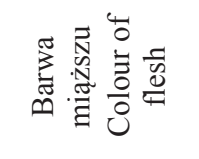 & \multicolumn{6}{|c|}{ 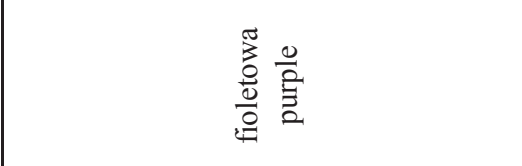 } & \multicolumn{2}{|c|}{ 营 } \\
\hline 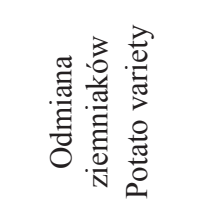 & 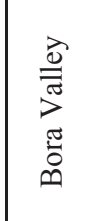 & 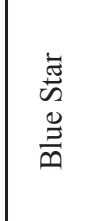 & $\stackrel{\frac{4}{5}}{\stackrel{5}{J}}$ & 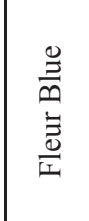 & 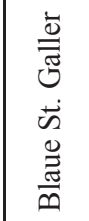 & 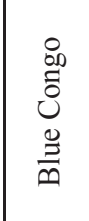 & 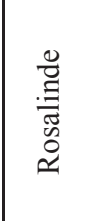 & 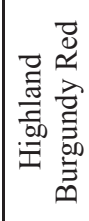 \\
\hline
\end{tabular}




\begin{tabular}{|c|c|c|}
\hline 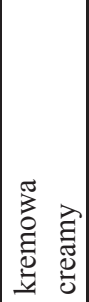 & ' & \\
\hline 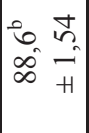 & , & \\
\hline $\begin{array}{ll}\infty & = \\
0 & = \\
\vec{N} & +1\end{array}$ & $\begin{array}{l}\text { ָे } \\
\text { @i }\end{array}$ & \\
\hline $\begin{array}{ll} & \infty \\
\tilde{\partial} & 0 \\
0 & 0 \\
\infty & 0\end{array}$ & $\begin{array}{c}\infty \\
\infty \\
\substack{\infty \\
i}\end{array}$ & \\
\hline $\begin{array}{cc}0 & 0 \\
\vec{N} & 0 \\
0 & 0 \\
0 & +\end{array}$ & ğ & \\
\hline $\begin{array}{ll}0 & + \\
2 & 0 \\
& 0 \\
- & 0 \\
+\end{array}$ & $\begin{array}{l}\stackrel{0}{\infty} \\
\infty \\
0\end{array}$ & \\
\hline 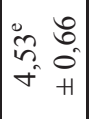 & $\stackrel{2}{\circ}$ & \\
\hline $\begin{array}{l}\infty \\
0 \\
0 \\
+ \\
i \\
i n \\
o \\
0\end{array}$ & ' & \\
\hline 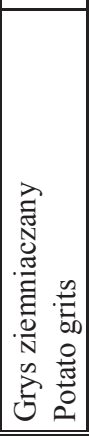 & 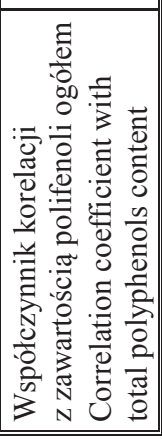 & \\
\hline
\end{tabular}


Różowa barwa suszy otrzymanych z ziemniaków odmian o czerwonym miąższu związana jest prawdopodobnie $\mathrm{z}$ większą stabilnością pochodnych pelargonidyny obecnych w tych ziemniakach od pochodnych petunidyny i malwidyny występujących w surowcu o fioletowym miąższu [13]. Korzystniejsza barwa suszy z ziemniaków o czerwonym zabarwieniu miąższu może wynikać także z tego, że do blanszowania tego surowca zastosowano roztwór kwasu cytrynowego, który skutecznie hamuje ciemnienie chemiczne w ziemniakach odmian o żółtym miąższu [10]. Zastosowanie zabiegu blanszowania ziemniaków odmian o fioletowym miąższu w roztworze kwasu winowego miało na celu zapobieżenie degradacji antocyjanów, jednak nie uchroniło surowca od zmian barwy zachodzących po obróbce termicznej. W procesie chemicznego ciemnienia ziemniaków pod wpływem powietrza wolny jon $\mathrm{Fe}^{2+}$ zostaje utleniony do jonu trójwartościowego, który reaguje $\mathrm{z}$ kwasem chlorogenowym uwolnionym podczas gotowania i nadaje szary kolor miąższu [7, 10]. Skutkiem tych procesów w odniesieniu do niektórych prób był beżowo-szary odcień otrzymanych suszy.

W przetwórstwie ziemniaków na susze stosuje się proces blanszowania w roztworach $\mathrm{SO}_{2} \mathrm{w}$ celu zachowania odpowiedniej barwy miąższu. We wcześniejszych badaniach wykazano, że zastosowanie blanszowania ziemniaków o barwnym miąższu w roztworach $\mathrm{SO}_{2}$ pozwala na zachowanie charakterystycznej barwy w gotowych suszach, jednak stwierdzono zmniejszenie zawartości polifenoli i antocyjanów odpowiednio o: 30 i $58 \%$ [21]. W porównaniu z barwą grysu ziemniaczanego przemysłowego badane susze z ziemniaków odznaczały się mniej wysyconą barwą, przy czym susze $\mathrm{z}$ czerwonych odmian ziemniaków charakteryzowały się bardziej intensywną barwą (wartości C średnio 12,6) niż susze z bulw odmian fioletowych (C średnio 6,8). Susze otrzymane $\mathrm{z}$ bulw odmian o fioletowym i czerwonym miąższu były ciemniejsze ( $\mathrm{L}^{*}$ w zakresie $\left.59,7 \div 71,44\right)$ w porównaniu z przemysłowym grysem z bulw o jasnym, tradycyjnym miąższu $\left(\mathrm{L}^{*}=86,09\right)$. Wśród suszy z ziemniaków o fioletowym miąższu najjaśniejszy był susz z ziemniaków odmiany 'Bora Valley', a najciemniejszy z 'Blaue St. Galler' (tab. 1). Jasność uzyskanych suszy w dużym stopniu zależała od zawartości w nich polifenoli $(\mathrm{r}=-0,701)$, a szczególnie antocyjanów.

\section{Aktywność przeciwutleniajaca i zawartość polifenoli w chrupkach}

Zastosowanie do produkcji przekąsek suszu z ziemniaków o fioletowym i czerwonym miąższu przyczyniło się do otrzymania produktu o nawet 2-krotnie większej zawartości związków polifenolowych ('Highland Burgundy Red' i 'Blue Star') w porównaniu z próbą kontrolną, którą były chrupki otrzymane na bazie przemysłowego grysu ziemniaczanego. Zawartość związków polifenolowych w przekąskach z udziałem suszu z odmian o fioletowym miąższu kształtowała się w granicach od 0,152 mg GAE/g s.m. ('Blue Congo') do 0,310 mg GAE/g s.m. ('Blue Star'), a z udziałem suszu z czerwonych ziemniaków wynosiła $0,230 \mathrm{mg}$ GAE/g s.m. ('Rosalinde') i 0,316 mg 
GAE/g s.m. ('Highland Burgundy Red') i zależała od zawartości polifenoli w suszach użytych do produkcji chrupek (tab. 2). Uzyskane przekąski zawierały podobną lub większą ilość polifenoli i odznaczały się większą aktywnością przeciwutleniającą w porównaniu z chrupkami otrzymanymi przez Nemś i Pęksę [22]. Większa zawartość związków polifenolowych $\mathrm{w}$ chrupkach wiązała się w wyższą aktywnością przeciwutleniającą otrzymanych przekąsek, szczególnie wyrażoną jako zdolność redukowania jonów żelaza - FRAP $(\mathrm{r}=0,947)$ i dezaktywacji kationorodników $\operatorname{ABTS}^{\circ+}(\mathrm{r}=0,831)$. Uzyskane wyniki znajdują potwierdzenie w badaniach innych autorów [12, 17], według których istnieje wysoka dodatnia korelacja pomiędzy aktywnością przeciwutleniającą i zawartością polifenoli w ziemniakach.

Tabela 2. Zawartość polifenoli ogółem i aktywność przeciwutleniająca chrupek

Table 2. Total polyphenols content and antioxidant activity of snacks

\begin{tabular}{|c|c|c|c|c|c|}
\hline \multirow[t]{2}{*}{$\begin{array}{l}\text { Odmiana ziemniaków } \\
\text { Potato variety }\end{array}$} & \multirow[t]{2}{*}{$\begin{array}{l}\text { Barwa miąższu } \\
\text { Colour } \\
\text { of flesh }\end{array}$} & \multirow[t]{2}{*}{$\begin{array}{l}\text { Polifenole ogółem } \\
\text { [mg GAE/g s.m.] } \\
\text { Total polyphenols } \\
\text { [mg GAE/g d.m.] }\end{array}$} & \multicolumn{3}{|c|}{ 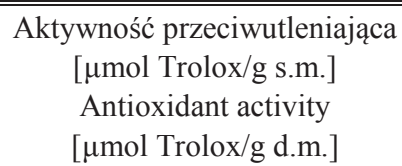 } \\
\hline & & & $\mathrm{ABTS}^{\circ+}$ & $\mathrm{DPPH}^{\circ}$ & FRAP \\
\hline Bora Valley & \multirow{6}{*}{$\begin{array}{l}\text { fioletowa } \\
\text { purple }\end{array}$} & $0,155^{\mathrm{d}} \pm 0,007$ & $\begin{array}{r}1,518^{\mathrm{f}} \\
\pm 0,163 \\
\end{array}$ & $\begin{array}{c}0,739^{\mathrm{d}} \\
\pm 0,048 \\
\end{array}$ & $\begin{array}{r}0,453^{\mathrm{e}} \\
\pm 0,056 \\
\end{array}$ \\
\hline Blue Star & & $0,310^{\mathrm{a}} \pm 0,017$ & $\begin{array}{l}2,051^{\mathrm{b}} \\
\pm 0,090\end{array}$ & $\begin{array}{l}1,057^{\mathrm{a}} \\
\pm 0,033\end{array}$ & $\begin{array}{r}0,958^{\mathrm{a}} \\
\pm 0,029\end{array}$ \\
\hline Valfi & & $0,245^{\mathrm{bc}} \pm 0,018$ & $\begin{array}{l}1,798^{\mathrm{cd}} \\
\pm 0,056\end{array}$ & $\begin{array}{l}0,813^{\mathrm{c}} \\
\pm 0,041\end{array}$ & $\begin{array}{c}0,877^{\mathrm{b}} \\
\pm 0,074 \\
\end{array}$ \\
\hline Fleur Blue & & $0,260^{\mathrm{b}} \pm 0,011$ & $\begin{array}{l}1,967^{\mathrm{bc}} \\
\pm 0,111\end{array}$ & $\begin{array}{l}0,852^{\mathrm{c}} \\
\pm 0,046\end{array}$ & $\begin{array}{l}0,811^{\mathrm{b}} \\
\pm 0,022\end{array}$ \\
\hline Blaue St. Galler & & $0,266^{\mathrm{b}} \pm 0,009$ & $\begin{array}{l}1,811^{\text {cd }} \\
\pm 0,254\end{array}$ & $\begin{array}{c}0,819^{c} \\
\pm 0,053\end{array}$ & $\begin{array}{l}0,720^{\mathrm{c}} \\
\pm 0,049\end{array}$ \\
\hline Blue Congo & & $0,152^{\mathrm{d}} \pm 0,005$ & $\begin{array}{l}1,582^{\text {ef }} \\
\pm 0,137\end{array}$ & $\begin{array}{l}0,727^{\mathrm{d}} \\
\pm 0,053\end{array}$ & $\begin{array}{c}0,476^{\mathrm{e}} \\
\pm 0,046\end{array}$ \\
\hline Rosalinde & \multirow{2}{*}{$\begin{array}{l}\text { czerwona } \\
\text { red }\end{array}$} & $0,230^{\mathrm{c}} \pm 0,012$ & $\begin{array}{l}1,612^{\mathrm{de}} \\
\pm 0,090\end{array}$ & $\begin{array}{l}0,731^{\mathrm{d}} \\
\pm 0,035\end{array}$ & $\begin{array}{r}0,583^{\mathrm{d}} \\
\pm 0,039 \\
\end{array}$ \\
\hline $\begin{array}{c}\text { Highland Burgundy } \\
\text { Red }\end{array}$ & & $0,316^{\mathrm{a}} \pm 0,021$ & $\begin{array}{l}2,637^{\mathrm{a}} \\
\pm 0,120\end{array}$ & $\begin{array}{c}0,923^{\mathrm{b}} \\
\pm 0,022\end{array}$ & $\begin{array}{r}0,957^{\mathrm{a}} \\
\pm 0,045\end{array}$ \\
\hline \multicolumn{2}{|c|}{ Próba kontrolna / Control sample } & $0,146^{\mathrm{d}} \pm 0,005$ & $\begin{array}{c}0,647^{\mathrm{g}} \\
\pm 0,195\end{array}$ & $\begin{array}{l}0,210^{\mathrm{e}} \\
\pm 0,054\end{array}$ & $\begin{array}{r}0,376^{\mathrm{f}} \\
\pm 0,048 \\
\end{array}$ \\
\hline \multicolumn{2}{|c|}{$\begin{array}{l}\text { Współczynnik korelacji z zawartością } \\
\text { polifenoli ogółem / Correlation coefficient } \\
\text { with total polyphenols content }\end{array}$} & - & 0,83 & 0,76 & 0,95 \\
\hline
\end{tabular}

Objaśnienia jak pod tab. 1 / Explanatory notes as in. Tab. 1. 
Właściwości fizykochemiczne chrupek

W przeprowadzonym doświadczeniu przekąski, do których produkcji zastosowano susz z ziemniaków odmian o fioletowym i czerwonym miąższu, charakteryzowały się nowymi cechami wizualnymi, niewystępującymi w tradycyjnych przekąskach otrzymanych na bazie grysu ziemniaczanego. Na kształtowanie barwy otrzymanych chrupek wpływ miał skład recepturowy mieszanek, przede wszystkim rodzaj użytego suszu ziemniaczanego, a także ilość i jakość antocyjanów zawartych w surowcu. Związki te częściowo uległy degradacji podczas procesu produkcji przekąsek, co wpłynęło na końcowe zabarwienie produktu gotowego [11].

Chrupki z udziałem suszy z fioletowych odmian ziemniaków były jasnobeżowe ('Blue Star', 'Valfi, Blue Congo'), beżowe ('Bora Valley', 'Fleur Blue') lub ciemnobeżowe ('Blue St. Galler'), a z czerwonych odmian - beżowo-różowe ('Rosalinde') lub różowe ('Highland Burgundy Red') - tab. 3. Zastosowanie suszu z ziemniaków o czerwonym miąższu odmiany 'Highland Burgundy Red' korzystnie wpłynęło na barwę chrupek, które charakteryzowały się różowym zabarwieniem, atrakcyjnym dla konsumentów, co potwierdziły przeprowadzone badania sensoryczne (tab. 4.). Chrupki otrzymane z suszu ziemniaków odmian o barwnym miąższu były ciemniejsze ( $\mathrm{L}^{*}$ w zakresie $55,34 \div 61,83)$ od przekąsek próby kontrolnej $\left(\mathrm{L}^{*}=74,38\right)$, które były kremowe, co mogło mieć wpływ na ich akceptację przez oceniających. Stopień nasycenia barwy przekąsek otrzymanych na bazie eksperymentalnych suszy z ziemniaków o barwnym miąższu zależał od rodzaju użytego suszu, wahał się w zakresie $15,5 \div 17,4$ i był mniejszy niż przekąsek próby kontrolnej $(C=20,9)-$ tab. 3 .

Przyczyną niewielkiego zróżnicowania barwy przekąsek była mało zróżnicowana barwa suszy użytych do ich produkcji. Otrzymano je z zastosowaniem blanszowania surowca wyłącznie w roztworach kwasów organicznych, z pominięciem typowego przeciwutleniacza wykorzystywanego $\mathrm{w}$ przemyśle ziemniaczanym do zachowania prawidłowej barwy przetworów, tj. roztworu zawierającego $\mathrm{SO}_{2}$, jak disiarczan(IV) czy wodorosiarczan(IV) sodu [30]. Barwa chrupek wynikała także z obecności w nich produktów reakcji Maillarda [15].

Zawartość thuszczu w wyrobach $\mathrm{z}$ dodatkiem suszu z ziemniaków o barwnym miąższu wahała się od 26,51 \% ('Highland Burgundy Red') do 29,66 \% ('Fleur Blue') i była podobna do zawartości tego składnika $\mathrm{w}$ chrupkach otrzymanych $\mathrm{z}$ udziałem przemysłowego grysu ziemniaczanego $(27,29 \%)$. Zawartość tłuszczu w przekąskach smażonych otrzymywanych z peletów może sięgać nawet $39 \%$ [14]. 


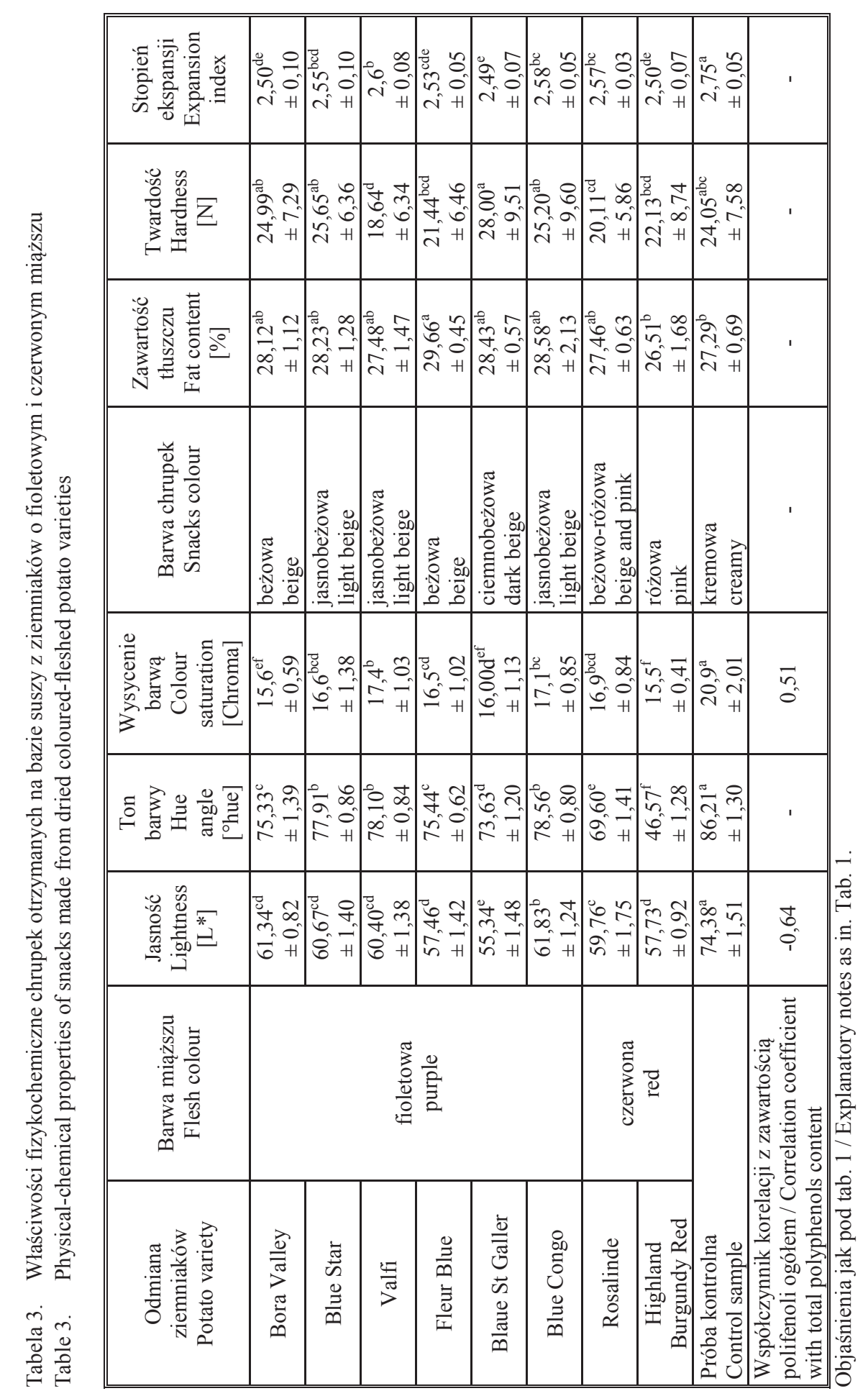


Chrupki wytworzone w procesie smażenia półproduktów (peletów) w gorącym oleju powinny charakteryzować się chrupką, delikatną konsystencją [24]. Najdelikatniejsze pod tym względem były wyroby otrzymane $\mathrm{z}$ udziałem suszu wytworzonego z ziemniaków o fioletowym miąższu odmiany 'Valfi' (18,64 N), które jednocześnie wyróżniały się wysokim stopniem ekspansji $(2,6)$. Wyroby uzyskane z udziałem suszu z ziemniaków o fioletowym miąższu odmiany 'Blaue St Galler' były najtwardsze $(28,0 \mathrm{~N})$ i jednocześnie ekspandowały w najmniejszym stopniu $(2,49)-$ tab. 3 . W przeprowadzonym doświadczeniu potwierdzono, że wraz ze zwiększaniem stopnia ekspansji wyroby charakteryzuje lepsza porowatość i chrupkość [28]. Kryterium koniecznym do uzyskania przekąsek o prawidłowym stopniu ekspansji jest odpowiednia zawartość skleikowanej skrobi w półprodukcie. Skrobia w recepturze wyrobów ekspandowanych, wytworzonych z peletów, powinna stanowić $80 \div 90 \%$, w tym ok. $15 \%$ - skrobia nieskleikowana, która w trakcie procesu ekstruzji ulega skleikowaniu, co zapewnia odpowiedni stopień ekspansji podczas smażenia [20].

\section{Ocena sensoryczna chrupek}

Chrupki poddano ocenie sensorycznej poprzez porównanie wybranych cech z 7-punktową skala opisową, na której 1 pkt oznaczał ocenę najniższą, natomiast 7 pkt - ocenę najwyższą. Oceniano barwę, konsystencję, wygląd, smak i zapach przekąsek.

Tabela 4. Wyniki oceny sensorycznej chrupek na bazie suszu z ziemniaków odmian o fioletowym i czerwonym miąższu oraz próby kontrolnej

Table 4. Results of sensory evaluation of snacks based on dried purple and red fleshed potatoes and on control sample

\begin{tabular}{|c|c|c|c|c|c|c|c|}
\hline $\begin{array}{c}\text { Odmiana } \\
\text { ziemniaków } \\
\text { Potato variety }\end{array}$ & $\begin{array}{l}\text { Barwa } \\
\text { miąższu } \\
\text { Colour of } \\
\text { flesh }\end{array}$ & $\begin{array}{c}\text { Barwa } \\
\text { Colour } \\
\text { [pkt] }\end{array}$ & $\begin{array}{c}\text { Konsystencja } \\
\text { Consistency } \\
\text { [pkt] }\end{array}$ & $\begin{array}{c}\text { Wygląd } \\
\text { Appearance } \\
\text { [pkt] }\end{array}$ & $\begin{array}{l}\text { Smak } \\
\text { Taste } \\
\text { [pkt] }\end{array}$ & $\begin{array}{c}\text { Zapach } \\
\text { Smell } \\
\text { [pkt] }\end{array}$ & $\begin{array}{c}\text { Ogólna } \\
\text { ocena } \\
\text { General } \\
\text { rating } \\
\text { [pkt] }\end{array}$ \\
\hline Bora Valley & \multirow{6}{*}{$\begin{array}{c}\text { fioletowa } \\
\text { purple }\end{array}$} & 5,7 & 6,1 & 6,1 & 6,4 & 6,7 & 6,20 \\
\hline Blue Star & & 5,6 & 5,9 & 5,9 & 6,1 & 6,4 & 5,96 \\
\hline Valfi & & 5,5 & 6,5 & 6,2 & 6,5 & 6,4 & 6,22 \\
\hline Fleur Blue & & 6,0 & 6,5 & 5,9 & 6,2 & 5,7 & 6,06 \\
\hline Blaue St. Galler & & 5,5 & 5,7 & 6,0 & 6,6 & 6,7 & 6,10 \\
\hline Blue Congo & & 6,0 & 6,4 & 6,1 & 6,4 & 6,3 & 6,24 \\
\hline Rosalinde & \multirow{2}{*}{$\begin{array}{l}\text { czerwona } \\
\text { red }\end{array}$} & 6,25 & 6,45 & 6,3 & 6,25 & 6,7 & 6,39 \\
\hline $\begin{array}{c}\text { Highland } \\
\text { Burgundy Red }\end{array}$ & & 7,0 & 6,6 & 6,5 & 6,9 & 6,9 & 6,78 \\
\hline $\begin{array}{l}\text { Próba kontrolna } \\
\text { Control sample }\end{array}$ & & 7,0 & 6,5 & 6,6 & 7 & 6,8 & 6,78 \\
\hline
\end{tabular}


Chrupki próby kontrolnej oraz na bazie suszu z ziemniaków odmiany 'Highland Burgundy Red' zostały ocenione najwyżej pod względem każdej z omawianych cech. Najniżej oceniono barwę chrupek z udziałem suszu z ziemniaków odmian 'Blue Star', 'Valfi' i 'Blaue St. Galler' (średnio 5,5 pkt). Najmniej akceptowaną konsystencją charakteryzowały się wyroby z suszem z ziemniaków 'Blaue St. Galler' (5,7 pkt), natomiast pod względem wyglądu i smaku najniżej ocenione zostały chrupki z suszu ziemniaków 'Blue Star' (odpowiednio 5,9 pkt i 6,1 pkt). Z kolei przekąski z suszu ziemniaków 'Fleur Blue' odznaczały się najmniej typowym zapachem (5,7 pkt) tab. 4 .

\section{Wnioski}

1. Zastosowanie blanszowania w roztworach słabych kwasów organicznych ziemniaków o fioletowym i czerwonym miąższu pozwoliło na zachowanie znacznej ilości związków polifenolowych w otrzymanych suszach, jednak nie zahamowało zmian wywołanych obróbką termiczną, tzw. ciemnieniem chemicznym.

2. Susze z odmian ziemniaków o fioletowym miąższu charakteryzowały się beżowofioletową, brązowo-fioletową bądź fioletową barwą, a otrzymane $\mathrm{z}$ nich chrupki były beżowe.

3. Susze z ziemniaków o czerwonym miąższu zachowały barwę różową, a otrzymane z nich chrupki charakteryzowały się beżowo-różowym bądź różowym zabarwieniem.

4. Chrupki z suszem z barwnych odmian ziemniaków zawierały więcej polifenoli $(4 \div 116 \%)$ i wykazywały wyższą aktywność przeciwutleniającą $\operatorname{DPPH}^{*}(3,5-\div$ 5 -krotnie), $\operatorname{ABTS}^{\circ+}(2,3-\div 4$-krotnie) FRAP (1,2- $\div$ 2,5-krotnie) w porównaniu $\mathrm{z}$ chrupkami otrzymanymi na bazie grysu przemysłowego.

5. Użycie suszy z ziemniaków o fioletowym i czerwonym miąższu pozwoliło na otrzymanie chrupek o większej zawartości związków biologicznie aktywnych i akceptowanych cechach sensorycznych. Ze względu na istotną rolę barwy w akceptacji konsumenckiej należy jednak zmodyfikować sposób otrzymywania suszy z surowca o barwnym miąższu.

Publikacja finansowana ze środków Katedry Technologii Rolnej i Przechowalnictwa Wydziału Biotechnologii i Nauk o Żywności Uniwersytetu Przyrodniczego we Wroctawiu.

\section{Literatura}

[1] AOAC 1995. Fat content in foods. Soxhlet extraction method. Official Method 963.15. AOAC International. 
[2] Wójtowicz A., Baltyn P.: Ocena wybranych cech jakościowych popularnych przekąsek ziemniaczanych. Żywność. Nauka. Technologia. Jakość, 2006, 2 (47), 112-123.

[3] Baryłko-Pikielna N., Matuszewska I.: Sensoryczne badania żywności. Podstawy. Metody. Zastosowania. Wyd. II. Wyd. Nauk. PTTŻ, Kraków 2014.

[4] Benzie I.E.F., Strain J.J.: The Ferric Reducing Ability of Plasma (FRAP) as a measure of "antioxidant power ": The FRAP assay. Anal. Biochem., 1996, 239, 70-76.

[5] Bołonkowska O., Pietrosiuk A., Sykłowska-Baranek K.: Roślinne związki barwne, ich właściwości biologiczne oraz możliwość wytwarzania w kulturach in vitro. Biul. Wydz. Farm. WUM., 2011, 1, $1-27$.

[6] Cavalcanti R.N., Santos D.T., Meireles M.A.A.: Non-thermal stabilization mechanisms of anthocyanins in model and food system - An overview. Food Res. Int., 2011, 44, 499-509.

[7] Friedman M.: Chemistry, biochemistry and dietary role of potato polyphenols. A review. J. Agric. Food Chem., 1997, 45, 1523-1540.

[8] Gao X., Bjork L., Trajkovski V., Uggla M.: Evaluation of antioxidant activities of rosehip ethanol extracts in different test systems. J. Sci. Food Agric., 2000, 80, 2021-2027.

[9] Giusti M.M., Wrolstad R.E.: Acylated anthocyanins from edible sources and their applications in food systems. Biochem. Eng. J., 2003, 14 (3), 217-225.

[10] Grudzińska M.: Czynniki wpływające na ciemnienie miąższu bulw po ugotowaniu. Ziemniak Polski, 2009, 4, 33-36.

[11] Gumul D., Korus J., Achremowicz B.: Wpływ procesów przetwórczych na aktywność przeciwutleniającą surowców pochodzenia roślinnego. Żywność. Nauka. Technologia. Jakość, 2005, 4 (45) Supl., 41-48.

[12] Hejtmánková K., Pivec V., Trnková E., Hamouz K., Lachman J.: Quality of coloured varieties of potatoes. Czech J. Food Sci., 2009, 27, 310-313.

[13] Kita A., Bąkowska-Barczak A., Hamouz K., Kułakowska K., Lisińska G.: The effect of frying on anthocyanin stability and antioxidant activity of crisps from red- and purple-fleshed potatoes (Solanum tuberosum L.). J. Food Compost. Anal., 2013, 32, 169-175.

[14] Kita A., Aniołowski K., Włodarczyk E.: Zmiany frakcji tłuszczowej w przechowywanych produktach przekąskowych. Zesz. Nauk. AR we Wrocławiu, 2003, 35 (2), 88-89.

[15] Kita A., Popiela-Kukuś K.: Wpływ dodatku wytłoków lnianych na wybrane właściwości smażonych chrupek ziemniaczanych. Acta Agrophysica, 2010, 16 (1), 69-77.

[16] Krzywiński T., Tokarczyk G.: Słone i pikantne przekąski na rynkach Polski i świata. Przem. Spoż., $2011,65,47-50$.

[17] Lachman J., Hamouz K., Sulc M., Orsak M., Pivec V., Hejtmankova A., Dvorak P., Cepl J.: Cultivar differences of total anthocyanins and anthocyanidins in red and purple-fleshed potatoes and their relations to antioxidant activity. Food Chem., 2009, 114, 836-843.

[18] Lachman J., Hamouz K., Orsák M., Pivec V., Hejtmánková K., Pazderů K., Dvorak P., Cepl J.: Impact of selected factors - Cultivar, storage, cooking and baking on the content of anthocyanins in coloured-flesh potatoes. Food Chem., 2012, 133 (4), 1107-1116.

[19] Lachman J., Hamouz K.: Red and purple coloured potatoes as a significant antioxidant source in human nutrition - a review. J. Plant Soil Environ., 2005, 51, 477-482.

[20] Lusas E.W., Rooney L.W.: Snack Food Processing. CRC Press, Boca Raton 2001, p. 639.

[21] Nemś A., Pęksa A., Kucharska A.Z., Sokół-Łętowska A., Kita A., Drożdż W., Hamouz K.: Anthocyanin and antioxidant activity of snacks with coloured potato. Food Chem., 2015, 172, 175-182.

[22] Nemś A., Pęksa A.: Polyphenols of coloured-flesh potatoes as native antioxidants in stored fried snacks. LWT-Food Sci. Technol., 2018, 97, 597-602.

[23] Peksa A., Kita A., Carbonell-Barachina A.A., Miedzianka J., Kolniak-Ostek J., Tajner-Czopek A., Rytel E., Siwek A., Mairka D., Drożdż W.: Sensory attributes and physiochemical feature of corn snacks as affected by different flour and extrusion conditions. Food Sci. Technol., 2016, 72, 26-36.

[24] Pęksa A., Kita A., Zięba T.: Wybrane właściwości smażonych chrupek ziemniaczanych z różnym dodatkiem błonnika. Żywność. Nauka. Technologia. Jakość, 2004, 3 (40), 106-113. 
[25] Re R., Pellegrini N., Proteggente A., Pannala A., Yang M., Rice Evans C.: Antioxidant activity applying an improved ABTS radical cation decolourisation assay. Free Rad. Biol. Med., 1999, 26, 1231-1237.

[26] Reddivari L., Hale A.L., Miller Jr J.C.: Determination of phenolic content, composition and their contribution to antioxidant activity in specialty potato selections. Am. J. Potato Res., 2007, 84, 275 282.

[27] Reyes L.F., Miller J.C., Cisneros-Zevallos L.: Antioxidant capacity, anthocyanins and total phenolics in purple- and red-fleshed potato (Solanum tuberosum L.) genotypes. Am. J. Potato Res., 2005, 82, 271-277.

[28] Trela A., Mościcki L.: Wpływ procesu ekstruzji na wybrane cechy jakościowe peletów zbożowych. Żywność. Nauka. Technologia. Jakość, 2007, 5 (54), 43-54.

[29] Yen G.C., Chen H.Y.: Antioxidant activity of various tea extracts in relation to their antimutagenicity. J. Agric. Food Chem., 1995, 46, 849-854.

[30] Zgórska K.: Jak uzyskać dobrą jakość suszonej kostki ziemniaczanej. Ziemniak Polski, 2011, 2, 1-4.

\section{QUALITY OF FRIED POTATOES AND SNACKS MADE FROM PURPLE AND RED FLESHED POTATOES}

S u m m a r y

The objective of the research was to determine the total polyphenol content, antioxidant activity, and colour of both the dried purple and red fleshed potatoes blanched in organic acids solutions and the potato snacks produced using those dried potatoes. The raw material studied were dried potatoes produced from tubers blanched in tartaric acid solution (purple fleshed potato varieties) or citric acid solution (red fleshed potato varieties); they constituted a semi-finished product to produce potato pellets that were, next, fried to make potato snacks. The content of polyphenols, antioxidant activity, and colour were determined in dried potatoes and potato snacks. In addition, the fat content was analyzed in the potato snacks as were their hardness, expansion index, and sensory features.

It was found that blanching the flesh-coloured potatoes in organic acids solutions made it possible to save a significant amount of polyphenols in dried potatoes; however, the blanching did not inhibit changes induced by thermal processing, i.e. the so-called chemical darkening. Dried purple fleshed potatoes were beige-purple, brown-violet, or purple, and snacks made from them were beige. The dried red fleshed potatoes maintained the pink colour and the snacks made from them were beige-pink or pink. Snacks produced from coloured-fleshed potato varieties contained more polyphenols $(4 \div 116 \%)$ and they had a higher antioxidant activity of $\mathrm{DPPH}^{\circ}(3.5 \div 5$ times higher $), \mathrm{ABTS}^{\circ+}(2.3 \div 4$ times higher $)$, and FRAP $(1.2 \div 2.5$ times higher) compared to a control sample. Using the purple and red fleshed potato varieties made it possible to produce snacks that were characterized by acceptable sensory characteristics; however, because of the important role of colour in consumer acceptance, the method of producing dried potatoes from raw coloured-fleshed potato tubers should be modified.

Key words: purple and red fleshed potatoes, blanching, dried potatoes, snacks, colour, polyphenols, antioxidant activity 